\title{
A case of varicella complicated with erysipelas
}

\section{Samia Mrabat, Hanane Baybay, Zakia Douhi, Sara Elloudi, Fatima Zahra Mernissi}

\author{
Department of Dermatology, Hassan II Hospital University, Fez, Morocco
}

Corresponding author: Dr. Samia Mrabat, E-mail: samiamrabat91@gmail.com

Sir,

A four-year old boy presented one week before the consultation with a febrile rush. It had began with small red dots on the torso, then progressed to the face and legs with emergence of small blisters which became umbilicated then evolved to crusts. The patient was given ibuprofen for the fever. 48 hours later, he developped a painful swelling and redness on the right thigh. At the physical examination, he had a 41 degree fever, an exanthema made of lesions at different stages consistent with the diagnosis of varicella, as well as an erythema and oedema of the right thigh, with no necrosis, blisters or purpura (Fig. 1). Blood tests showed an elevated level of $\mathrm{C}$ reactive protein at 235 , leucocytosis and a normal level of CPK. The diagnosis of erysipelas was then retained and the patient was put under antibiotics with a good outcome (Fig. 2).

Varicella is usually a benign and self-limited disease manifested by mild systemic symptoms,

characteristic rash, and low-grade fever. The clinical course is generally mild in healthy children. However, studies have showed that the use of NSAIDs (nonsteroidal anti-inflammatory drugs) was associated with an increased risk of severe skin and soft tissue complications [1]. Therefore fever and pain associated with varicella or herpes zoster should be treated with paracetamol, not a NSAID.

\section{Consent}

The examination of the patient was conducted according to the Declaration of Helsinki principles.

The authors certify that they have obtained all appropriate patient consent forms. In the form the patient(s) has/have given his/her/ their consent for his/her/their images and other clinical information to be reported in the journal. The patients understand that their

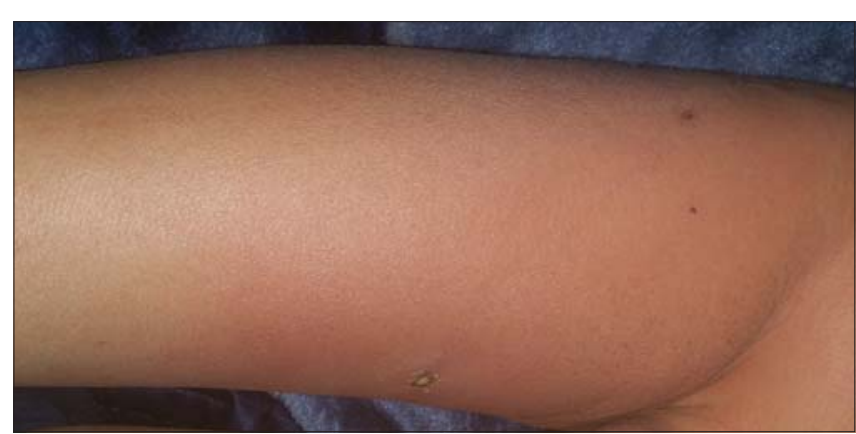

Figure 1: Swelling and redness on the right thigh centered by an erosion, as well as hemorrhagic crusts at the periphery.

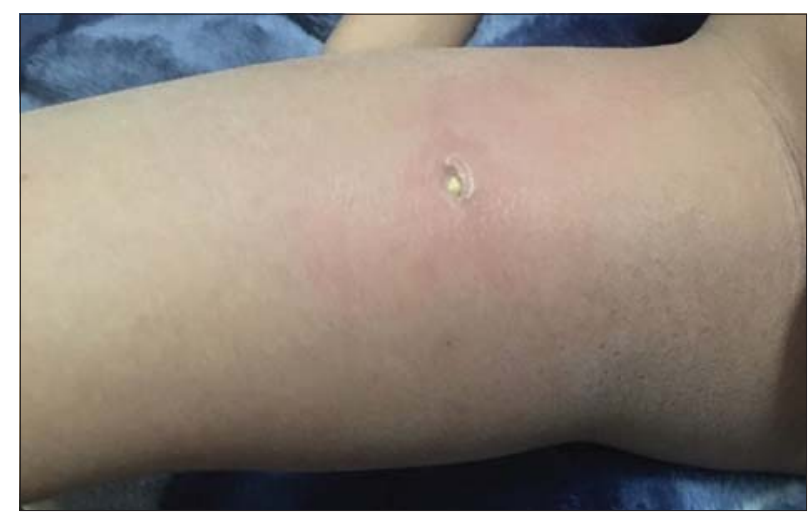

Figure 2: Improvement of the redness and the swelling 72 Shours after the beginning ot the antibiotic therapy.

names and initials will not be published and due efforts will be made to conceal their identity, but anonymity cannot be guaranteed.

\section{REFERENCES}

1. Gershon AA, Breuer J, Cohen JI, Cohrs RJ, Gershon MD, Gilden D, et al. Varicella zoster virus infection. Nat Rev Dis Primers. 2015;1:15016.

Copyright by Samia Mrabat, et al. This is an open access article distributed under the terms of the Creative Commons Attribution License, which permits unrestricted use, distribution, and reproduction in any medium, provided the original author and source are credited. Source of Support: Nil, Conflict of Interest: None declared.

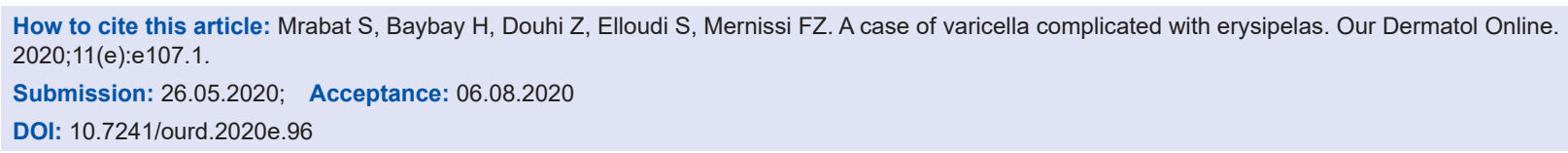

